\title{
Changes on Speech Transmission Characteristics by Types of Mask
}

\author{
Jeongho Jeong1, Mina Kim², Youngsun Kim³ \\ ${ }^{1}$ Fire Insurers Laboratories of Korea (FILK), Yeoju, Korea \\ ${ }^{2}$ Music Bridge International (MBI), Seoul, Korea \\ ${ }^{3}$ Department of Music, Graduate School of Seoul National University, Seoul, Korea
}

\author{
Received: July 16, 2020 \\ Revised: August 28, 2020 \\ Accepted: September 22, 2020 \\ Correspondence: \\ Youngsun Kim, PhD \\ Department of Music, \\ Graduate School \\ of Seoul National University, \\ 1 Gwanak-ro, Gwanak-gu, \\ Seoul 08826, Korea \\ Tel: +82-2-880-7939 \\ Fax: +82-2-878-7064 \\ E-mail: youngsunkim@snu.ac.kr
}

\begin{abstract}
Purpose: Given the increased levels of fine and ultrafine dust, as well as the spread of COVID-19, current opinion is that most people will wear a face mask such a KF94 mask for a long time. To test speech transmission through the face masks, various types of masks including dust masks available in the market at the time of the study were tested under laboratory conditions. Methods: Fourteen types of masks worn on a head and torso simulator (HATS) and test signals were played on a speaker installed in the mouse position of the HATS. Speech Transmission Index (STI) and the speech level in the octave band were measured at distances of $1 \mathrm{~m}$ and $2 \mathrm{~m}$. Results: STI at a distance of $2 \mathrm{~m}$ was decreased to $3.4-5.7 \%$ and speech levels in the octave band at $4 \mathrm{kHz}$ or higher were also decreased when wearing disposable masks and a cotton mask. KF80 and KF94 masks showed decreased STI similar to those of disposable masks; however, a decrease in the speech level was observed at the octave bands of above $2 \mathrm{kHz}$. Dust masks and single-cartridge half-face respirators showed approximately $11.2 \%$ and $33.7 \%$ to $39.3 \%$ decreases in STI levels, respectively. Conclusion: When wearing masks, STI and the speech level was decreased in the high-frequency bands. However, speech level differences at high frequencies may be related to the increased voice level of the speaker and the understanding of consonants with the masks for several hours in living and working environments.
\end{abstract}

Key Words: Masks, Speech communication, Speech level, Speech Transmission Index.

\section{INTRODUCTION}

미세먼지와 초미세먼지 발생이 증가함에 따라 미세먼지로부 터 호흡기를 보호하기 위한 마스크 사용이 지속적으로 증가하 고 있다. 2015년의 경우 전년 대비 미세먼지 마스크 매출이 약 200\% 성장하였으며(Cheon \& Kim, 2015), 2019년 4월 보도자료 에 의하면 미세먼지가 심했던 기간 중 미세먼지 마스크의 편의 점 매출이 전주 대비 약 $900 \%$ 정도 증가하였다(Kim, 2018). 2020년에는 COVID-19로 인해 보건용 마스크 공급량이 659만 개/일에서 1,291만개/일로 증가하였으며(Kang, 2020), COVID-19 예방을 위한 마스크 착용에 대한 관심이 급격히 증가하 였다. 이와 같이 바이러스 감염과 확산 방지를 위해 보건용 마 스크를 장시간 착용하고 생활하거나 업무를 수행함에 따라 마 스크 착용으로 인한 여러 가지 불편한 점이 제시되고 있다. 고 객 상대가 많은 콜센터 업무의 경우 마스크 착용으로 인한 숨

(c) This is an Open Access article distributed under the terms of the Creative Commons Attribution Non-Commercial License (https://creativecommons.org/licenses/by-nc/4.0) which permits unrestricted non-commercial use, distribution, and reproduction in any medium, provided the original work is properly cited.
쉬기 어려움과 고객이 상담원의 말소리가 잘 안 들린다는 불만 이 제기되는 점이 보도되었다(Choi, 2020; Kwon, 2020).

의료기관 의료진의 의료용 마스크와 산업현장 근무자의 산 업용 마스크 및 방독면 착용 시 원활한 음성 의사소통에 제한 을 받게 되어 이를 보완하기 위해 음성 전달막(speech membrane)이 설치된 elastomeric half-mask air-purifying respirator (EAPR) 제품이 출시되거나 음성 대화를 보조하는 장치 등이 고안되고 있다. 보건용 마스크의 기준으로 분진포집효율, 안면부흡기저항과 누설률을 평가하여 등급을 부여하고 있으나 마스크 착용 시 음성 전달 저하 등에 대한 기준이 보완될 필요 가 있다. 음성 전달 특성과 음성 명료도를 평가하는 많은 지표 들이 제안되어 있지만, 마스크의 음성 전달 측정 방법으로는 IEC 60286-16 (International Electrotechnical Commission, 2011)에 규정된 음성 전달 지수(Speech Transmission Index, STI)와 Modified Rhyme Test (MRT)가 국외 연구에서 사용되 었다. 음성 전달 지수는 발화자의 음성을 청취자가 명료하게 청 취하는 정도를 정량적으로 평가하기 위한 지표로 0에서 1사이 의 값으로 발화된 음성이 왜곡되는 정도를 평가한다. 음성 전 
달 지수는 1970년대에 개발되어 1988년 IEC 국제표준으로 제 정되었으며, 이후 성별에 따른 차이 반영과 방송설비의 명료도 평가지표로 음성 전달 지수를 기반으로 한 Speech Transmission Index for Public Address System (STIPA) 반영 등 지속적 으로 개정되고 있다. 음성 전달 지수가 모든 다양한 음성 전달 환경을 모두 평가할 수는 없지만, 방송설비, 유무선 통신 시스 템, 음성 알람, 청취 보조 시스템(assistive hearing system)과 실 내 공간에서의 음성 환경에서 사용되어 국제적으로 유용함을 인정받고 있다.

우리나라에서는 마스크에 대한 음성 전달 특성 관련 연구가 이루어지지 않아 관련 자료가 부족한 실정이다. 최근 보건용 마스크의 사용 확산에 따라 시장에서 판매되고 있는 여러 마 스크의 음성 전달 특성에 대한 조사가 필요하여, 다양한 마스 크를 대상으로 평가하였다. 미세먼지 발생 증가에 따라 마스크 를 착용하는 인구가 증가하고 있었으며, COVID-19 사태로 모 든 국민이 마스크 특히 보건용 마스크를 착용하고 있다. 산업 현장에서도 여러가지 유기화합물 및 분진을 차단하기 위한 산 업용 마스크를 착용하고 있다. 마스크 착용 시 입을 통해서 발 성되는 대화음을 마스크가 차단하기 때문에 일부 마스크 착용 자가 음성 대화와 청취에 불편을 호소할 수 있다. 특히 의료용 마스크의 경우 의료진의 명확하고 원활한 의사소통을 위해 마 스크 착용에 따른 음성 명료도 저하를 최소화하는 것이 필요 하다. 우리나라의 경우 마스크 착용에 따른 음성 명료도, 음성 전달 저하 등에 연구나 실태 조사는 이루어지지 않았으며, 군 용 방독면의 경우 음성 보조 장치에 대한 특허가 출원되어 제 한적으로 사용되고 있다. 방독면에 대한 보급확대 방안과 규격 기준 재설정을 위한 연구(Korea Research Institute of Standards and Science, 2009)가 수행되었지만 음성 전달 특성 평 가 방법과 기준에 대한 사항은 수행되지 않았다.

국외의 경우 수술용 마스크, N95 마스크와 EAPR 등을 대 상으로 음성 전달 지수를 배경소음 크기를 변화시키면서 $1.5 \mathrm{~m}$ 거리에서 측정하였다(Palmiero et al., 2016). 배경소음이 52.5 $\mathrm{dB}(\mathrm{A})$ 인 경우 마스크 두께가 얇은 수술용 마스크의 음성 전달 지수 변화는 3 4\%, 몰드형 N94 마스크는 음성 전달 지수가 $13 \sim 17 \%$, 정화통을 설치하여 사용하는 $\mathrm{EAPR}$ 의 음성 전달 지 수는 42 45\% 정도 변화되는 것으로 보고하였다. 또한 배경소 음이 증가함에 따라 선형적으로 음성 전달 지수가 감소되는 경 향을 확인하였다. 수술용 마스크를 착용한 경우 음성 언어 이 해 정도를 정상 청력 그룹과 난청그룹으로 나누어 청취 평가를 수행한 결과 수술용 마스크 착용에 따른 음성 언어 이해에 부 정적인 영향은 없는 것으로 조사되었다(Mendel et al., 2008). 의료진을 대상으로 수술용 마스크, EAPR에 대하여 MRT를 a등록특허, 10-0329707-0000, 방독마스크용 마이크장치
수행한 결과 수술용 마스크의 음성 명료도는 1 17\%, powered air-purifying respirator (PAPR)을 착용한 경우 음성 명료도 는 $11 \%$ 정도 낮아지는 것으로 나타났다(Radonovich et al., 2010). 일반 수술용 마스크와 투명한 수술용 마스크에 대한 음 성 이해 정도를 정상 청력자와 난청자에 대하여 평가한 결과 투 명한 수술용 마스크를 착용한 경우 발음 시의 시각정보가 함께 제공되어 음성 인지에 도움이 되는 것으로 나타났다(Atcherson et al., 2017). 이와 같이 기존의 마스크 관련 연구는 수술용 또 는 의료용 마스크를 대상으로 의료 환경에서의 음성 정보 전달 과 이해에 대하여 평가하였다. 최근에는 COVID-19로 인해 일 반적인 생활 환경, 사무와 작업 환경에서도 보건용 마스크를 장 시간 착용하고 있어, 조용한 생활 및 업무 환경에서의 마스크 착 용에 따른 음성 명료도와 전달 음성 음압 레벨 변화 등에 대한 평가가 필요하다.

본 연구에서는 2020년 현재 널리 사용되고 있는 일회용 마 스크, 면마스크와 보건용 마스크(KF80, KF94), 산업용 방진 마스크 등을 대상으로 조용한 배경소음 환경에서 마스크 자체 의 음성 전달 특성 변화를 평가하기 위하여 음향 측정용 마네 킹에 착용시킨 다음 사회적 거리두기로 권장되고 있는 $2 \mathrm{~m}$ 거 리와 $1 \mathrm{~m}$ 거리에서 음성 전달 지수와 주파수 대역별 음성 레벨 을 측정하여 비교하였다. 측정 결과를 통해 마스크 착용으로 인한 음성 전달 저하 특성을 정량적으로 비교할 수 있으며, 측 정 결과는 다양한 마스크, 안면 보호구 및 방독면 등의 음성 전 달 특성 개선을 위한 기초 자료로 활용될 수 있다. 또한 $\mathrm{COV}-$ ID-19 극복을 위해 마스크를 착용하는 경우 음성 명료도 저하 정도를 정량적으로 알려 불필요한 논쟁을 최소화하고 서로 이 해할 수 있는 자료를 제공하고자 한다. 이를 통해 모든 국민이 당면한 COVID-19 사태를 현명하고 슬기롭게 극복하는 데 기 여하고자 한다. 향후 지속적인 연구 및 투자를 통해 마스크, 방 독면, 헬멧 등 다양한 생활 및 산업 현장에서 활용되는 장치의 음성 전달 향상 기술 연구, 개발까지 확대될 수 있다.

\section{MATERIALS AND METHODS}

\section{연구 재료}

마스크 착용에 따른 음성 전달 특성 변화를 조사하기 위하 여 시장에서 유통되고 있는 14종 마스크(Figure 1)를 대상으로 음성 전달 지수와 음성 레벨을 $1 \mathrm{~m}$ 거리와 사회적 거리두기 거 리로 권장하고 있는 $2 \mathrm{~m}$ 거리에서 측정하여 비교하였다. 음성 전달 지수는 IEC 60286-16에 규정된 지표로 산출방법은 직접 방법과 간접 방법으로 구분할 수 있다. 직접 방법은 발생된 신 호가 왜곡되는 정도(modulated transfer function, MTF)를 측 정하여 변조 주파수와 옥타브 대역별로 98 개 세트로 측정하여 


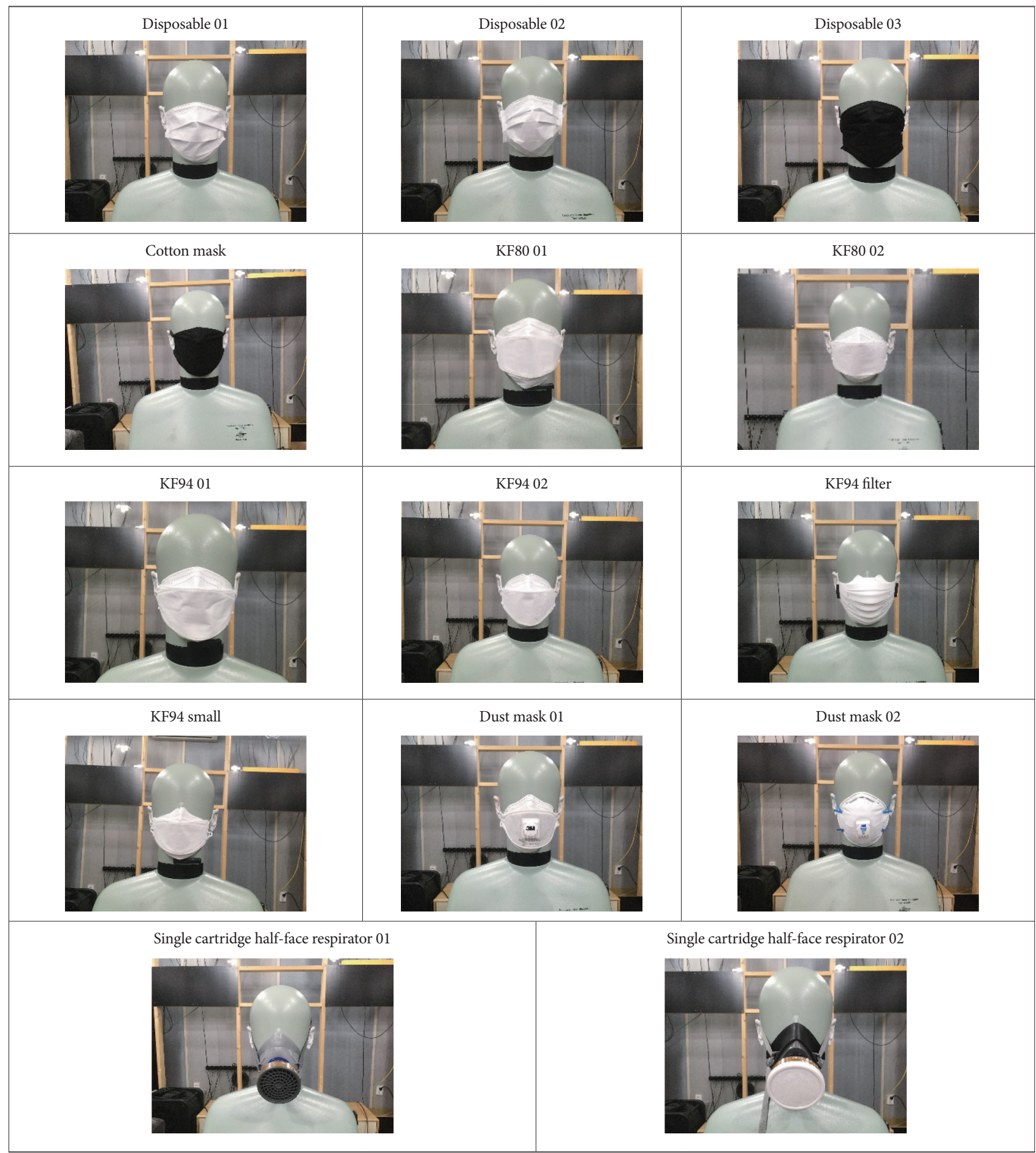

Figure 1. Fourteen types of masks used in the study.

산출한다. IEC 60286-16에 수록된 Figure 2는 음성 전달지수 산출을 위한 MTF에 대한 개념도이다. 변조 주파수 $\mathrm{f}_{\mathrm{m}}$ 에서의 MTF는 수식 [1]로 계산한다. 또한 유효 신호대 잡음비는 수식 [2]로 계산한다. 음성 전달 지수는 $\mathrm{m}(\mathrm{F})$ 와 $\mathrm{SNR}_{\mathrm{eff}}$ 를 조합하여 계산한다. 또한 간접 방법은 충격응답으로 측정한 감쇠곡선으 로 계산하는 방법으로 수식 [3]을 이용하여 계산한다.

$$
\begin{aligned}
& m(F)=\frac{m_{\mathrm{o}}(F)}{m_{\mathrm{i}}(F)} \\
& S N R_{\text {eff }}=10 \lg \left(\frac{m(F)}{1-m(F)}\right)
\end{aligned}
$$




$$
m_{k}\left(f_{m}\right)=\frac{\left|\int_{0}^{\infty} h_{k}(t) e^{-j 2 \pi f_{\mathrm{m}} t} d t\right|}{\int_{0}^{\infty} h_{k}(t)^{2} d t} \cdot\left[1+10^{-S N R_{k} / 10}\right]^{-1}
$$

여기서, $h_{k}(t)$ 는 $k$ 옥타브 대역의 충격응답, $\mathrm{f}_{\mathrm{m}}$ 은 변조 주파수, $\mathrm{SNR}_{\mathrm{eff}}$ 은 신호대잡음비 $(\mathrm{dB})$ 를 나타낸다.

음성 전달 지수 측정을 각 주파수 대역별로 반복 측정하면 시간과 노력이 많이 소요되어 최근에는 위의 측정 절차가 통합 된 전용 측정 장비를 사용하여 측정한다. 간접 방법은 ISO 3382-3 (International Organization for Standardization, 2012) 에 규정되어 있으며 주로 건축물 내부 공간의 음성 전달 지수 평가를 위해 사용된다.

본 연구에서는 음성 전달 특성 측정을 위해 음성 발생 기능 이 있는 음향 측정용 마네킹(Head \& Torso Simulator Type4128C, Brüel \& Kjær, Nærum, Denmark)의 마우스 소스에 서 STI 측정 음원을 발생시키고 STI 측정을 위해서는 전용 측 정 장치(XL2, NTi Audio, Urdorf, Switzerland)를 사용하였다.

측정 대상 마스크는 14종이었으며, 2020년 4월 기준으로 시 중에서 널리 사용되고 있는 일회용 마스크 3종, 면 마스크 1종, $\mathrm{KF} 80$ 황사 마스크 2종, KF94 보건용 마스크 3 종(대형 2종, 소 형 1종)을 대상으로 하였다. 이에 추가하여 야외 체육활동용으 로 판매되는 KF94 필터를 교체하여 사용할 수 있도록 실리콘 으로 마스크 외부를 성형한 필터 교체형 마스크 1종도 KF94 마스크와 비교하기 위하여 선정하였다. 이에 추가하여 온라인 쇼핑몰에서 판매량을 참고하여 산업 현장에서 널리 사용되고 있는 분진 마스크 2종과 정화통 교체형 방진 마스크 2종을 대 상으로 하였다. 정화통 교체형 분진 마스크의 경우 마스크 전 면에 1개의 정화통을 장착하는 형식을 대상으로 하였으며, 정 화통은 유기화합물용 정화통(single cartridge hlaf-face respi- rator 01)과 유기화합물 방진 겸용 정화통(single cartridge hlaf-face respirator 02)을 각각 적용하였다. 마스크에 의한 음 성 전달 지수 변화를 확인하기 위해 마스크를 음향 측정용 마 네킹에 설치하지 않은 상태에서의 측정 결과를 기본값으로 하 고 14종 마스크를 적용하고 측정하여 비교하였다.

\section{음성 전달 특성 측정 방법}

음향 측정용 마네킹의 마우스 소스에서 발생시킨 음성 전달 지수 측정용 음원의 크기는 $1 \mathrm{~m}$ 거리에서 $71 \mathrm{~dB}(\mathrm{~A})$ 이 되도록 설정하였다. 이는 기존 연구(Han \& Lee, 2020)에서 제시한 일 상적으로 대화할 때의 음성 크기 “크게”에 해당하는 평균 레벨 [여성 $68.9 \mathrm{~dB}(\mathrm{~A})$, 남성 $69.3 \mathrm{~dB}(\mathrm{~A})$ ]을 바탕으로 하였다. 측정 대상 공간은 실제 주거공간의 음향 특성과 유사하게 구현된 방 음부스에서 실시하였다. 방음부스의 크기는 길이 약 $7.5 \mathrm{~m}$, 폭 약 $5 \mathrm{~m}$, 높이 $2.4 \mathrm{~m}$ 의 공간으로 폴리에스테르 흡음재에 패브릭 이 덧쓰워진 재료로 마감되었으며, 쇼파, TV 거치대 등 거실 가 구를 배치하였다.

음성 명료도 측정 시 배경소음은 $26.9 \mathrm{~dB}(\mathrm{~A})$ 였으며, 잔향시 간은 $1 \mathrm{kHz}$ 대역에서 $0.26 \mathrm{~s}$ 였으며, 배경소음과 잔향시간 스펙 트럼은 Figure 2 와 같다. $2 \mathrm{kHz}$ 이하 대역에서는 배경소음과 측정음원과의 레벨 차가 $15 \mathrm{~dB}(\mathrm{~A})$ 이상이었으며, $4 \mathrm{kHz}$ 와 8 $\mathrm{kHz}$ 대역에서는 평균 $17.4 \mathrm{~dB}(\mathrm{~A}), 8.5 \mathrm{~dB}(\mathrm{~A})$ 의 레벨 차가 확보 된 것으로 확인되었다. 음향 측정용 마네킹에 마스크를 착용시 키는 경우 코지지대를 최대한 밀착되도록 하였으며, 끈 조절이 가능한 마스크의 경우 마스크 본체와 음향 측정용 마네킹의 안면부가 밀착되도록 설치하여 측정하였다.

\section{RESULTS}

14 종 마스크를 음향 측정용 마네킹에 착용시킨 다음 $1 \mathrm{~m}$ 와
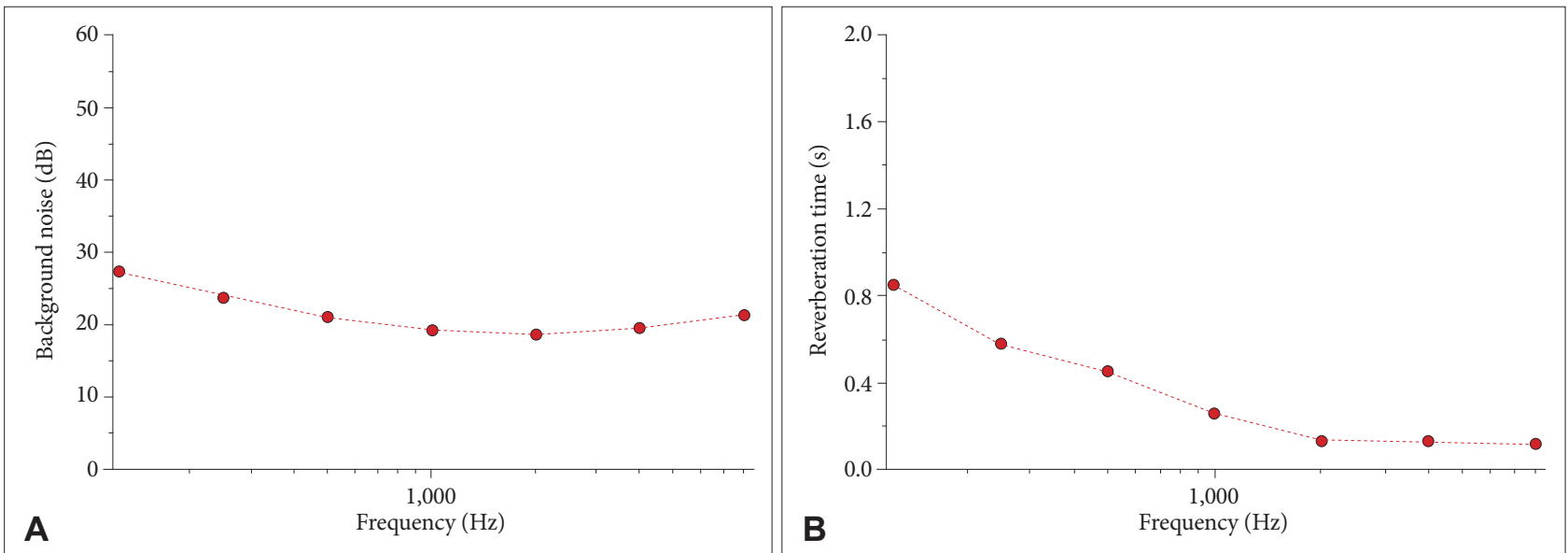

Figure 2. Background noise level (A) and reverberation time (B) where Speech Transmission Index was measured. 
$2 \mathrm{~m}$ 거리에서 음성 전달 지수와 음성 레벨을 측정하여 Table 1 과 Table 2에 각각 정리하였다. ISO 9921은 실내 공간, 방송설 비, 위험 및 긴급 상황에서의 음성 전달 특성을 평가하는 표준 으로 1996년에 제정되었으며, $1 \mathrm{~m}$ 거리에서의 발성 크기에 대 한 $\mathrm{A}$-가중 음압 레벨, 주관적인 음성 명료도 평가 방법과 예측 절차 등을 규정하고 있다. Table 1 의 음성 전달 지수 측정 결과 는 ISO 9921 (International Organization for Standardization, 2003)의 음성 명료도 등급에 따라 3단계로 구분하였다. 음성 명료도가 우수한 것은 excellent, 양호한 것은 good, 명료도가 낮은 것은 fair로 표기하였다. 음성 전달 지수의 경우 마스크를 적용하지 않을 시 $1 \mathrm{~m}$ 거리에서 $0.90,2 \mathrm{~m}$ 거리에서는 0.89 로 거리 증가에 따라 0.01 감소되었다. 일회용 마스크의 경우 $1 \mathrm{~m}$ 거리에서 $0.90 \sim 0.89,2 \mathrm{~m}$ 거리에서는 0.86 0.84로 나타났으며, 일회용 마스크 착용에 의해 음성 전달 지수는 거리별로 0.01 , 0.04 감소하였으며, 기본 조건에 비해 거리 증가에 의한 음성 전달 지수 감소가 0.03 으로 증가하였다. 면 마스크의 경우 일회 용 마스크에 비해 두껍기는 하지만 음성 전달 지수 변화 정도 는 일회용 마스크와 유사한 것으로 나타났다. KF80 마스크는 황사 및 미세먼지 차단용으로 판매되고 있다. 2종의 KF80 마 스크(대형)의 음성 전달 지수 측정 결과, $1 \mathrm{~m}$ 거리에서는 0.88 , 0.87 로 $2 \mathrm{~m}$ 거리에서는 $0.84,0.83$ 으로 나타났다. 기본 조건에 비해 거리별로 각각 $0.025,0.055$ 정도 음성 전달 지수가 감소하 였다. 거리 증가에 따른 음성 전달 지수 감쇠는 0.04 로 일회용 마스크나 면 마스크와 유사한 결과를 나타냈다. 최근 가장 많

Table 1. Comparison of Speech Transmission Index (STI) measured at $1 \mathrm{~m}$ and $2 \mathrm{~m}$ distance from the mouse source of Head \& Torso Simulator

\begin{tabular}{|c|c|c|c|}
\hline \multirow[b]{2}{*}{ Type of mask } & \multicolumn{2}{|c|}{ STI } & \multirow{2}{*}{$\begin{array}{c}\text { Level of } \\
\text { speech } \\
\text { perception }\end{array}$} \\
\hline & $1 \mathrm{~m}$ & $2 \mathrm{~m}$ & \\
\hline Base line & 0.90 & 0.89 & $\mathrm{E}$ \\
\hline Disposable 01 & 0.89 & 0.85 & $\mathrm{E}$ \\
\hline Disposable 02 & 0.90 & 0.86 & $\mathrm{E}$ \\
\hline Disposable 03 & 0.89 & 0.84 & $\mathrm{E}$ \\
\hline Cotton mask & 0.90 & 0.86 & $\mathrm{E}$ \\
\hline KF80 01 & 0.88 & 0.84 & $\mathrm{E}$ \\
\hline KF80 02 & 0.87 & 0.83 & $\mathrm{E}$ \\
\hline KF94 01 & 0.87 & 0.84 & $\mathrm{E}$ \\
\hline KF94 02 & 0.87 & 0.83 & $\mathrm{E}$ \\
\hline KF94 filter & 0.86 & 0.79 & $\mathrm{E}$ \\
\hline KF94 small & 0.89 & 0.83 & $\mathrm{E}$ \\
\hline Dust mask 01 & 0.83 & 0.79 & $\mathrm{E}$ \\
\hline Dust mask 02 & 0.84 & 0.79 & $\mathrm{E}$ \\
\hline Single cartridge hlaf-face respirator 01 & $0.65(G)$ & $0.59(\mathrm{~F})$ & - \\
\hline Single cartridge hlaf-face respirator 02 & 0.58 & 0.54 & $\mathrm{~F}$ \\
\hline
\end{tabular}

E: excellent, G: good, F: fair
이 사용되고 있는 KF94 마스크는 대형 2종, 소형 1종과 필터 교 체형에 대하여 측정하였다. KF94 대형 마스크에 대한 음성 전 달 지수 측정 결과 거리별로 $1 \mathrm{~m}$ 에서는 $0.87,2 \mathrm{~m}$ 에서는 0.83 , 0.84 로 KF80 마스크와 유사한 것으로 나타났다. KF94 필터 교 체형 마스크의 경우 필터 부착 외부 몰드가 실리콘으로 성형되 고 전면 통기구는 가로로 3 개, 원형 통기구가 좌우측에 각각 6 개씩 있었다. 음성 전달 지수 측정 결과 $1 \mathrm{~m}$ 에서는 $0.86,2 \mathrm{~m}$ 거리에서는 0.79 로 대형 KF94 마스크에 비해 낮게 측정되었다. 음원으로부터 거리가 멀어짐에 따라 음성 전달 지수 감쇠가 크 게 나타났는데, 이는 교체형 필터를 고정하기 위한 외부 실리콘 몰드에 의해 음원에서 발생되는 음에너지가 차단되기 때문으로 판단된다. 일회용과 보건용 마스크의 음성 전달 지수 측정 결 과는 $1.5 \mathrm{~m}$ 거리에서 음성 명료도를 평가한 기존 연구(Palmiero et al., 2016)의 결과와 배경소음 크기는 다르지만 유사한 결과로 나타났다.

소형 KF94 마스크의 경우 $1 \mathrm{~m}$ 거리에서는 0.89 로 $2 \mathrm{~m}$ 에서 는 0.83 으로 $1 \mathrm{~m}$ 거리에서 음성 전달 지수가 높게 나타났는데 이는 측정 대상 음향 측정용 마네킹의 크기가 성인의 평균 머 리 크기와 안면부 크기를 바탕으로 하고 있어 어린이용으로 판 매되고 있는 소형 KF94 마스크를 착용시켰을 경우 상대적으 로 안면부를 차단하는 면적이 작기 때문으로 판단된다. 마스크 의 음성 전달 특성 측정, 평가 방법을 마련하는 경우 소형 마스 크의 특성을 충분히 반영한 시험 방법과 관련 기준 수립이 필 요하며, 소형 마스크 측정을 위한 소형 음향 측정용 마네킹 등 의 제안이 필요하다.

Table 2. Comparison of A-weighted sound pressure level (SPL) measured at $1 \mathrm{~m}$ and $2 \mathrm{~m}$ distance from the mouse source of Head \& Torso Simulator

\begin{tabular}{lcc}
\hline \multirow{2}{*}{ Type of mask } & \multicolumn{2}{c}{ SPL (dBA) } \\
\cline { 2 - 3 } & $1 \mathrm{~m}$ & $2 \mathrm{~m}$ \\
\hline Base line & 71.0 & 67.8 \\
Disposable 01 & 70.6 & 67.6 \\
Disposable 02 & 71.1 & 68.0 \\
Disposable 03 & 71.0 & 67.7 \\
Cotton mask & 70.6 & 67.3 \\
KF80 01 & 70.1 & 67.1 \\
KF80 02 & 70.5 & 67.2 \\
KF94 01 & 70.3 & 67.3 \\
KF94 02 & 69.8 & 67.0 \\
KF94 filter & 70.9 & 67.8 \\
KF94 small & 70.2 & 67.2 \\
Dust mask 01 & 69.7 & 66.7 \\
Dust mask 02 & 69.5 & 66.5 \\
Single cartridge half-face respirator 01 & 67.4 & 66.8 \\
Single cartridge half-face respirator 02 & 69.5 & 65.7 \\
\hline
\end{tabular}


산업현장에서 널리 사용되고 있는 방진 마스크의 경우 주요 산업 현장 작업에서 음성 대화가 산업 안전에 중요한 영향을 미칠 수 있어 음성 전달 지수 변화를 측정하였다. 몰드형 방진 마스크 2 종과 정화통을 안면 정면부에 1 개 장착하는 마스크 2종 에 대하여 측정하였다. 몰드형 방진 마스크의 경우 $1 \mathrm{~m}$ 거리에 서는 $0.83,0.84$ 로 $2 \mathrm{~m}$ 거리에서는 모두 0.79 로 보건용 마스크 에 비해 음원으로부터의 음에너지 차단이 큰 것으로 나타났다. 방진 마스크를 착용하더라도 음성 명료도 평가 결과는 가장 우수한 등급에 해당되었다. 정화통을 사용하는 방진 마스크 2 종은 실리콘 재질의 밀폐형 몰드에 정화통을 설치하는 구조로 되어 있어 안면부에 밀착되어 직접음이 마스크 외부로 전달되 기 어려운 구조를 갖고 있다. 음성 전달 지수 측정 결과 각각 1 $\mathrm{m}$ 거리에서 $0.65,0.58$ 로 $2 \mathrm{~m}$ 거리에서는 $0.59,0.54$ 로 보건용 마스크에 비해 0.26 정도 낮았다. 거리 증가에 따른 음성 전달 지수 감쇠는 0.04 0.06으로 보건용 마스크와 유사한 정도로 나타났다. 방진 마스크와 유사한 형상의 N95 마스크와 EAPR 의 음성 전달 지수 측정 결과는 $52.5 \mathrm{~dB}(\mathrm{~A})$ 이상의 배경소음 레 벨에서 측정한 기존 연구(Palmiero et al., 2016)와 유사한 경향 을 나타냈다. 그러나, 기존 연구 결과보다는 음성 전달 지수가 덜 저하되었는데, 이는 배경소음의 크기에 의한 영향이다. 방진 마스크의 경우 음성 전달 지수 및 음성 명료도 저하가 크기 때 문에 소음이 크게 발생되는 산업 현장에서 방진 마스크를 착용 한 상태에서 명료한 음성 대화는 어려울 수 있다.

Table 2는 음성 전달 지수 측정 시의 음성 레벨에 대한 A-가 중 음압 레벨 분석 결과이다. 마스크를 착용하지 않은 기본 조 건에서 $1 \mathrm{~m}$ 거리에서는 $71.0 \mathrm{~dB}(\mathrm{~A}), 2 \mathrm{~m}$ 거리에서는 67.8 $\mathrm{dB}(\mathrm{A})$ 로 거리 증가에 따라 $3.2 \mathrm{~dB}(\mathrm{~A})$ 줄어들었다. 일회용 마스 크 3종의 경우 음성 레벨의 평균이 $1 \mathrm{~m}$ 에서는 $70.9 \mathrm{~dB}(\mathrm{~A}), 2 \mathrm{~m}$ 에서는 $67.7 \mathrm{~dB}(\mathrm{~A})$ 였으며 거리 감쇠는 $3.1 \mathrm{~dB}(\mathrm{~A})$ 이었다. 주파 수 대역별 음성 레벨 스펙트럼은 Figure 3과 같으며, 음성 레벨
변화는 주로 4 8 kHz 대역에서 $2.6 \mathrm{~dB}, 4.3 \mathrm{~dB}$ 정도 감소되는 것으로 나타났다. 면 마스크의 경우 음성 레벨 저감은 0.4 $\mathrm{dB}(\mathrm{A}), 0.5 \mathrm{~dB}(\mathrm{~A})$ 로 크지 않았으며, Figure 4에서와 같이 8 $\mathrm{kHz}$ 대역에서 $2.7 \mathrm{~dB}$ 정도 감소되었다.

$\mathrm{KF} 80$ 마스크의 경우 $1 \mathrm{~m}$ 에서는 평균 $70.3 \mathrm{~dB}(\mathrm{~A}), 2 \mathrm{~m}$ 거리 에서는 $67.2 \mathrm{~dB}(\mathrm{~A})$ 크기로 음성이 전달되었으며 거리 증가에 따른 감쇠는 $3.1 \mathrm{~dB}(\mathrm{~A})$ 로 기본 조건의 경우와 유사하지만, Figure 3에서와 같이 2 8 kHz 대역의 음성 레벨이 $1 \mathrm{~m}$ 거리에 서는 $2.2 \mathrm{~dB}, 3.8 \mathrm{~dB}, 6.5 \mathrm{~dB}$ 감소하는 것으로 나타났다. $2 \mathrm{kHz}$ 이상 대역의 음성은 자음 발음과 관련된 음성 명료도 저하와 관련이 있을 것으로 사료되며, 마스크를 착용하지 않은 경우와 유사하게 고주파수 대역 음성을 전달하기 위해서는 화자가 더 크게 고주파수 대역 음을 발음해야 한다.

KF94 마스크의 경우 $1 \mathrm{~m}$ 거리에서의 음성 레벨은 70.1 $\mathrm{dB}(\mathrm{A}), 2 \mathrm{~m}$ 에서는 $67.2 \mathrm{~dB}(\mathrm{~A})$ 로 거리 증가에 따라 $2.9 \mathrm{~dB}(\mathrm{~A})$ 줄어들었으며, 주파수 대역별로는 Figure 5에서와 같이 $1 \mathrm{~m}$ 거 리에서 $2 \sim 8 \mathrm{kHz}$ 대역의 음성 레벨이 각각 2.4, 5.3, $6.7 \mathrm{~dB}$ 줄 어드는 것으로 나타나 KF80 마스크보다 고주파수 대역의 음 성 레벨이 더 크게 줄어들었다. KF94 마스크의 경우 음성 전 달 지수 결과는 KF80 마스크와 유사하였지만 음성 레벨 측정 결과 고주파수 대역의 감쇠가 크게 나타나 동일한 조건에서 KF94 마스크를 착용한 경우 마스크를 착용하지 않은 경우보 다 고주파수 대역의 음성이 작게 전달되는 것으로 확인되었다. 마스크 착용 시 음성이 잘 안 들린다는 불편은 고주파수 대역 음성음 레벨 차단으로 인한 것임을 알 수 있다. KF94 소형 마 스크의 음성 레벨 감소는 KF94 대형과 유사한 것으로 나타났 으며, 주파수 대역별 음성 레벨 변화 폭은 Figure 6과 같이 대 형보다 0.2 1.5 dB 정도 작았다. 필터 교체형 KF94 마스크의 경우 $1 \mathrm{~m}$ 거리의 $\mathrm{A}$-가중 음성 레벨은 $70.9 \mathrm{~dB}(\mathrm{~A})$ 로 기본 조건 과 유사하게 나타났는데, 이는 Figure 5에서와 같이 $1 \mathrm{kHz}$ 대
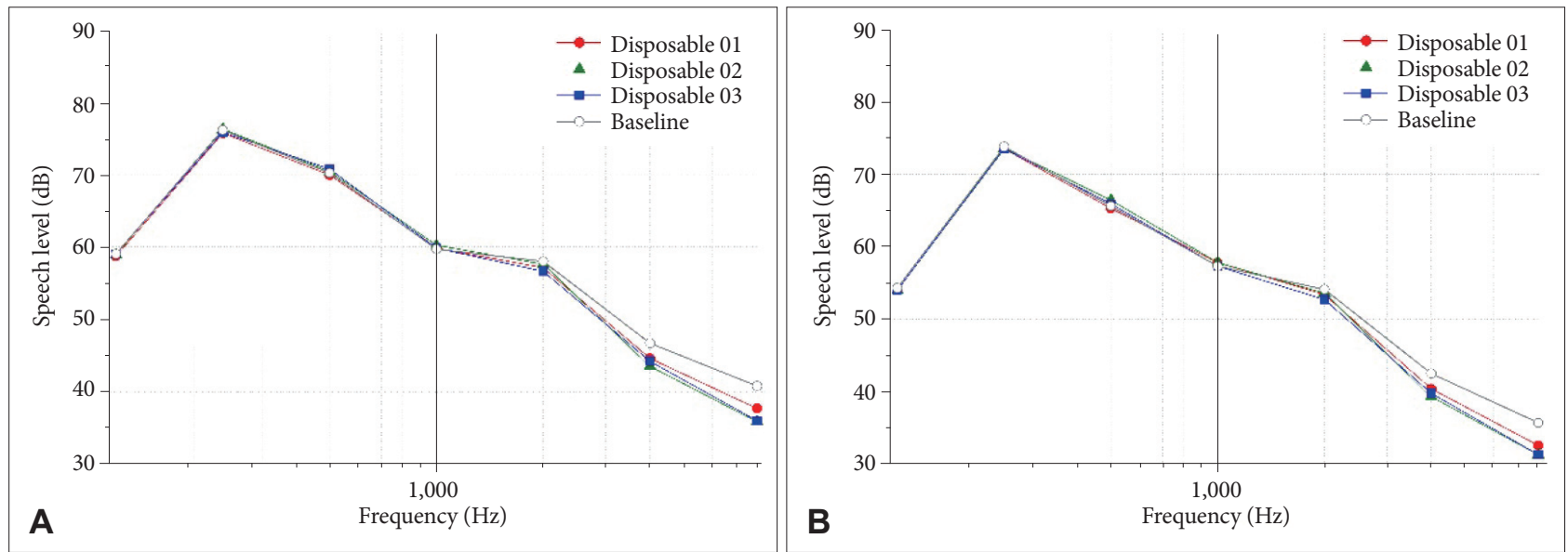

Figure 3. Speech level spectra of disposable masks at $1 \mathrm{~m}(\mathrm{~A})$ and $2 \mathrm{~m}(\mathrm{~B})$ distance. 

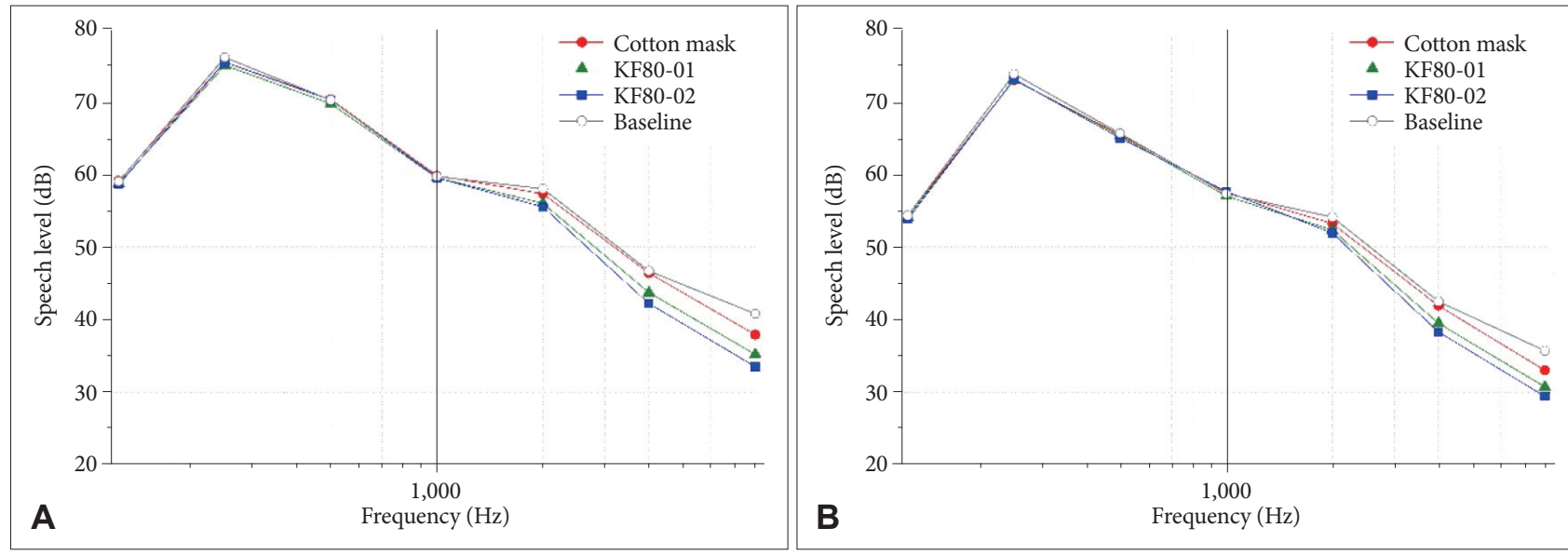

Figure 4. Speech level spectra of KF80 masks and cotton mask at $1 \mathrm{~m}(\mathrm{~A})$ and $2 \mathrm{~m}$ (B) distance.
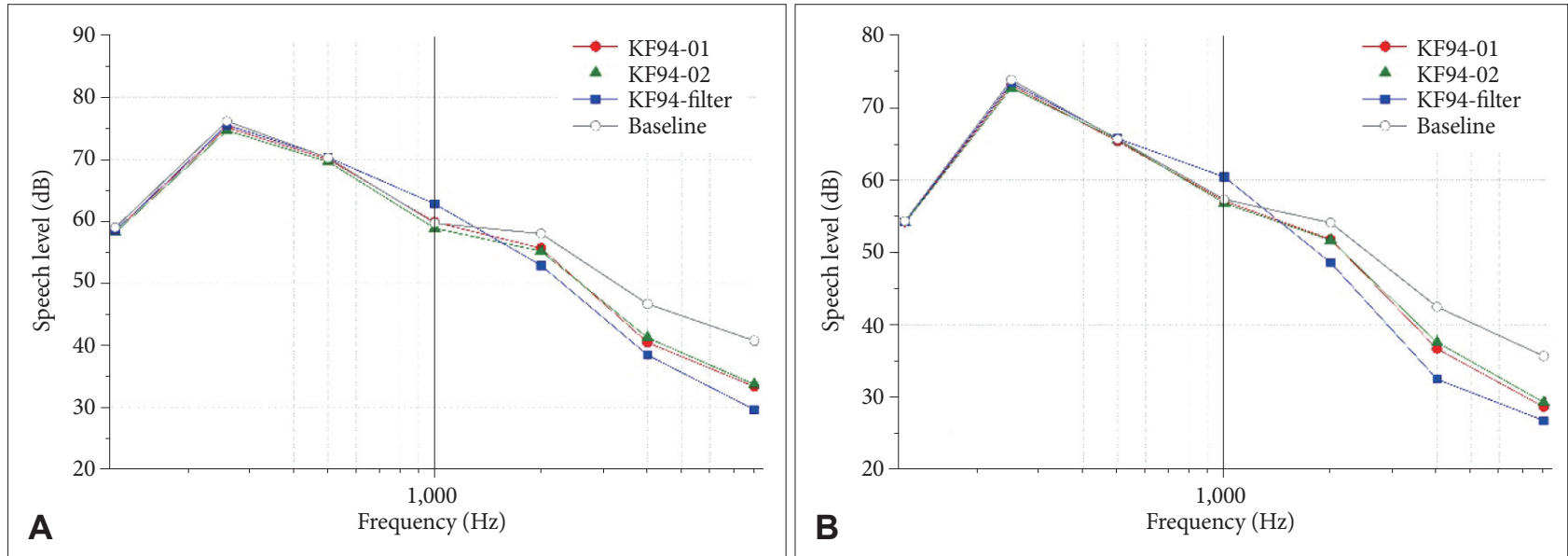

Figure 5. Speech level spectra of KF94 masks and KF94 mask with filter type at $1 \mathrm{~m}$ (A) and $2 \mathrm{~m}$ (B) distance.

역에서 음성 레벨이 증가했기 때문이다. $1 \mathrm{kHz}$ 대역의 음성 레 벨 증가는 필터 교체형 마스크의 실리콘 재질 외피가 음성 재 현 시 함께 진동하여 증가되는 것으로 판단된다. 그러나 $2 \mathrm{kHz}$ 이상 음성 대역의 음성 레벨 감쇠는 $2 \mathrm{~m}$ 거리의 경우 KF94 마 스크에 비해 $3.2 \mathrm{~dB}, 4.7 \mathrm{~dB}, 2.2 \mathrm{~dB}$ 더 많은 것으로 나타났다.

방진 마스크의 음성 레벨 측정 결과 $1 \mathrm{~m}$ 거리에의 음성 레벨 이 일회용 마스크보다는 $1.3 \mathrm{~dB}(\mathrm{~A})$, 보건용 마스크에 비해서는 평균 $0.6 \mathrm{~dB}(\mathrm{~A})$ 정도 낮았다. 몰드형으로 성형된 방진 마스크 의 재질이 일회용이나 보건용 마스크에 비해 두껍기 때문으로 판단되며, 마스크의 두께와 구성층이 증가함에 따라 음성 레벨 및 음성 전달 지수는 반비례하는 경향을 확인할 수 있다. 방진 마스크의 음성 레벨 스펙트럼 변화 $(1 \mathrm{~m}$ 거리)는 Figure 6과 같 이 보건용 마스크와 유사하게 $2 \mathrm{kHz}$ 이상 대역에서만 줄어드 는 것으로 나타났지만, 레벨 차는 $2 \mathrm{kHz}$ 에서 $4.4 \mathrm{~dB}, 4 \mathrm{kHz}$ 에 서 $8.7 \mathrm{~dB}, 8 \mathrm{kHz}$ 에서 $7.8 \mathrm{~dB}$ 로 보건용 마스크보다는 많이 줄 어들지만 실리콘으로 외피가 구성된 필터 교체형 마스크보다 는 덜한 것으로 나타났다.
정화통을 전면에 붙여 사용하는 방진 마스크의 경우 몰드 구조가 실리콘 재질로 구성되어 있어 안면부와 밀착하게 되고 배기 밸브를 통해 음성이 외부로 전달되기 때문에 음성 레벨 감소가 가장 큰 것으로 나타났다. 두가지 정화통 설치형 방진 마스크의 음성 레벨 특성이 다르게 나타나는 것은 single cartridge half-face respirator 01의 경우 배기 밸브의 위치가 안면 부 아래쪽에 바닥방향으로 설치되어 있고 배기 밸브 외부에 추 가 플라스틱 몰드가 설치되어 음성 전달에 어려운 구조를 하고 있기 때문이다. 정화통 설치형 방진마스크의 주파수 대역별 평 균 음성 레벨 감소 $(1 \mathrm{~m}$ 거리)는 $1 \mathrm{kHz}$ 대역부터 유효하게 나타 나고 있으며, Figure 7에서와 같이 $1 \mathrm{kHz}$ 대역에서는 $6.2 \mathrm{~dB}, 2$ $\mathrm{kHz}$ 에서는, $19.4 \mathrm{~dB}, 4 \mathrm{kHz}$ 는 $16.4 \mathrm{~dB}, 8 \mathrm{kHz}$ 에서는 $14.3 \mathrm{~dB}$ 로 측정 대상 마스크 중에서 가장 큰 것으로 나타났으며, 배경 소음이 높은 사용환경에서 이와 같은 마스크를 착용하면 명료 한 음성 대화가 어려울 수 있다. $2 \mathrm{~m}$ 거리의 스펙트럼의 경우 single cartridge half-face respirator 01 의 $1 \mathrm{kHz}$ 대역 레벨이 기본 조건 보다 높게 나타났는데, 이는 배기 밸브 방향과 외부 

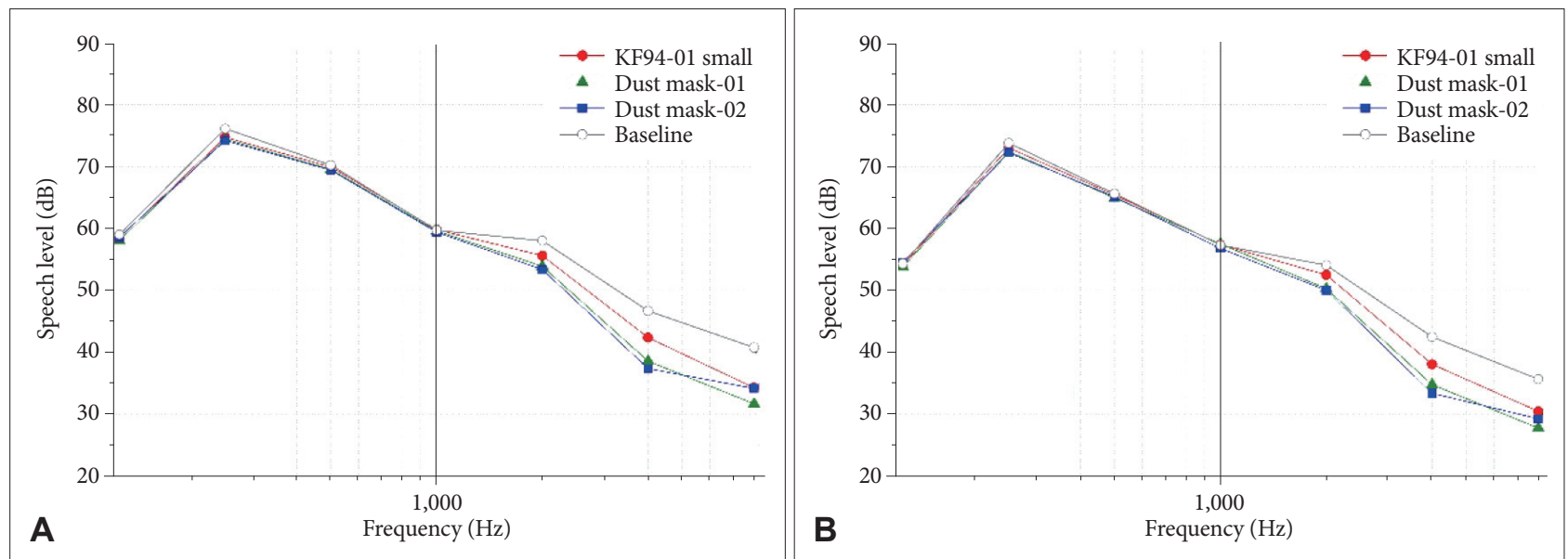

Figure 6. Speech level spectra of small size KF94 mask and dust masks at $1 \mathrm{~m}$ (A) and $2 \mathrm{~m}$ (B) distance.
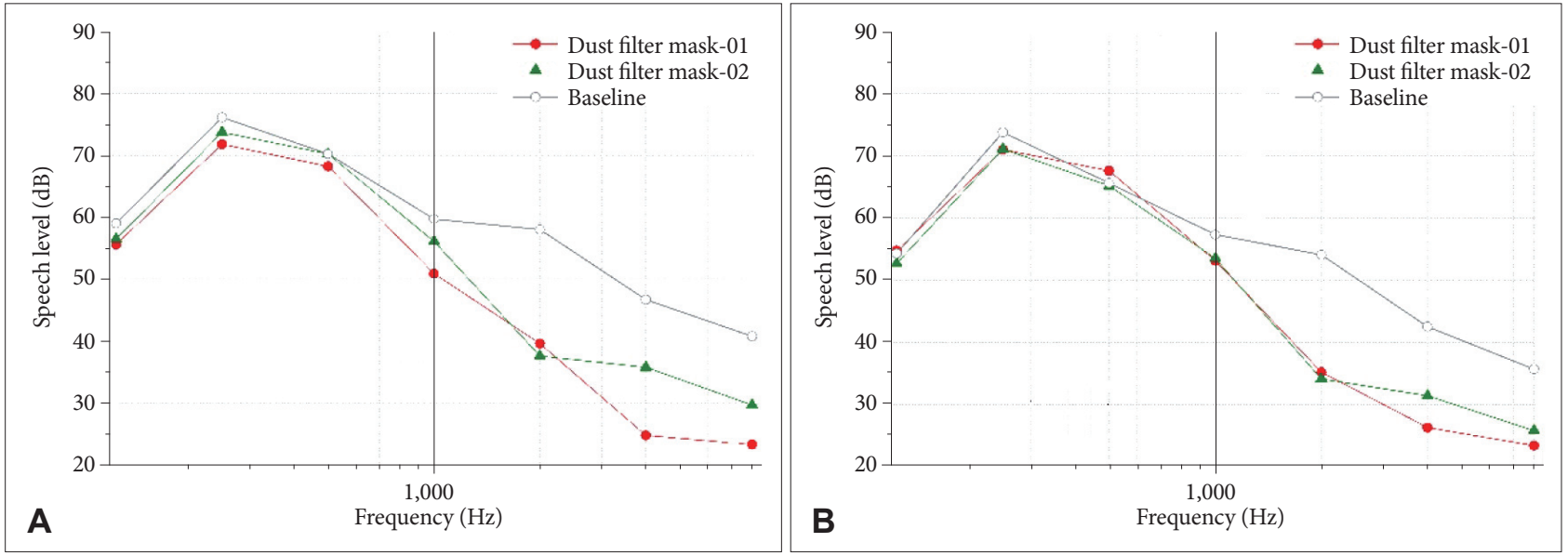

Figure 7. Speech level spectra of dust masks with filter attached type at $1 \mathrm{~m}(\mathrm{~A})$ and $2 \mathrm{~m}(\mathrm{~B})$ distance.

플라스틱 몰드에 의해 음향 측정용 마네킹 가슴과 바닥을 통한 반사음으로 전달되었기 때문이다.

\section{DISCUSSIONS}

최근 COVID-19 사태로 인해 모든 국민들이 불편을 감수하 고 마스크를 착용하며 생활하고 업무하고 있다. 마스크 착용으 로 인한 불편 중의 한 가지는 말소리가 정확하게 전달되지 않을 수 있다는 것이다. 실제로 여러 기업의 소비자 안내 전화에서 마스크 착용으로 인해 음성이 정확하게 전달되지 않을 수 있다 는 점을 미리 고지하고 있다. 식품의약품안전평가원의 보건용 마스크 기준 규격에 대한 가이드라인(National Institute of Food and Drug Safety Evaluation, 2019)에서는 분진포집효율, 안면부흡기저항과 누설률을 평가하는 방법을 규정하고 있으며 평가결과를 바탕으로 식품의약품안전처에서 관련 인증을 내주 고 있다. 우리나라의 경우 시판되고 있는 여러 가지 마스크에
대한 음성 전달 특성을 조사한 결과가 없다. 이에 본 연구에서 는 현재 우리나라에서 널리 사용되고 있는 일반 마스크, 보건 용 마스크와 방진 마스크 14 종을 구매하여 음성 전달 지수와 음성 레벨을 실제 주거 환경과 유사하게 구현한 배경소음이 낮 은 실험실에서 측정하였다. 측정은 음향 측정용 마네킹의 마우 스 소스를 사용하였으며, $1 \mathrm{~m}$ 거리와 사회적 거리두기 거리로 권장하고 있는 $2 \mathrm{~m}$ 거리에서 측정하여 분석하였다.

14 종의 마스크에 대한 음성 레벨과 스펙트럼 분석 결과 마스 크를 구성하는 재질의 두께, 밀도와 구성층의 증가에 따라 마 스크 외부로 전달되는 음성 레벨은 일회용 마스크의 경우 평균 $0.1 \mathrm{~dB}(\mathrm{~A}), \mathrm{KF} 80, \mathrm{KF} 94$ 마스크는 평균 $0.65 \mathrm{~dB}(\mathrm{~A})$ 정도 줄어 들었다. 또한, 측정점의 거리가 $1 \mathrm{~m}$ 에서 $2 \mathrm{~m}$ (사회적 거리두기 권 장 거리)로 멀어짐에 따라 약 $3 \mathrm{~dB}(\mathrm{~A})$ 정도 줄어드는 것으로 나 타났다. 이는 마스크를 착용하고 사회적 거리두기 권장 거리를 지키는 경우 상대방에게 전달되는 음성 레벨이 $3 \mathrm{~dB}(\mathrm{~A})$ 이상 줄 어들어 마스크를 착용하지 않고 밀접한 거리에서 대화하는 경우 
보다는 의사소통이 다소 불편할 수 있다는 것을 확인하였다.

마스크 착용으로 인해 음성 전달 지수가 줄어드는 정도는 마 스크를 착용하지 않은 경우에 비해 일회용 마스크와 면 마스크 는 3.4 5.7\%, KF80과 KF94 보건용 마스크는 3.4 6.8\%로 나 타났다. KF94 필터를 실리콘 몰드에 교체하여 사용하는 마스 크는 실리콘 몰드에 의해 음성 전달 지수가 $11.2 \%$ 감소하였으며, 방진 마스크도 동일한 수준으로 나타났다. 음성 명료도 등급은 모두 'Excellent (STI > 0.74)’로 동일하게 평가되었다. 그러나 이 는 마스크를 착용하면 음성이 다소 명확하지 않게 전달될 수 있 음을 의미한다. 정화통을 안면의 전면부에 부착하는 single cartridge half-face respirator를 착용하면 음성 전달 지수가 33.7 $39.3 \%$ 까지 감소하여 음성 명료도 등급이 'Excellent'에서 'Fair' 수준으로 낮아져, 음성이 명료하게 전달되기 어려워진다.

음성 명료도 평가 결과 보건용 마스크를 착용하여도 마스크 를 착용하지 않은 경우와 동일한 등급으로 평가되었지만, 음성 레벨과 스펙트럼 분석 결과 일회용 마스크와 보건용 마스크를 착용하면 $2 \mathrm{kHz}$ 이상 대역의 음성 레벨이 줄어들어 마스크를 착용하지 않은 경우보다는 자음 발음을 명확하게 알아듣기 어 려울 수 있다. 또한 동일한 음성 명료도를 유지하기 위해서는 말하는 사람이 고음을 더 크게 말해야 할 것으로 판단된다. 방 진 마스크의 음성 레벨과 고음 감쇠는 보건용 마스크보다 더 큰 것으로 나타났으며, 정화통을 사용하는 방진 마스크를 착용 하면 고음부 음성 레벨이 매우 크게 감소하는 것으로 나타났 다. 본 연구 결과는 배경소음이 매우 낮은 실험실 조건에서 음 성 명료도를 측정한 결과로 배경소음의 영향이 작게 반영되었 지만, 배경소음 높은 실제 사용환경에서는 배경소음이 명료한 음성전달을 방해하기 때문에 정화통을 사용하는 방진 마스크 를 착용하면 음성 전달 및 대화가 어려울 것이다.

본 연구는 일회용 마스크, $\mathrm{KF} 80, \mathrm{KF} 94$ 및 방진 마스크를 대상으로 매우 조용한 실험실 환경에서 음성 레벨과 음성 전달 지수를 평가하였으며, 이는 다양한 마스크의 자체 성능 평가결 과이다. 향후 실내 공간의 소리 울림, 배경소음 등 다양한 실제 마스크 착용 조건을 반영한 연구가 필요하다. 일반적으로 위험 조건이나 긴급 상황에서 마스크를 주로 착용하는 것을 고려하 면 마스크를 착용하더라도 명확하고 명료한 음성 전달이 가능 한 마스크와 음성 전달 보조 장치 등의 개발 및 보급이 필요한 것으로 판단된다. 이를 위해 보건용, 수술용 및 산업용 마스크 의 음성 전달 특성을 측정, 평가하는 방안과 기준 수립을 위한 기초 연구와 함께 다양한 마스크가 사용되는 실제 환경 조건에 서의 음성 전달 특성 측정과 우리말을 사용한 음성 전달 특성 평가, 설문 등에 관한 연구가 필요하다.

중심 단어 : 마스크·음성 대화·음성 레벨·음성 전달 지수.
Ethical Statement

N/A

Acknowledgments

N/A

Declaration of Conflicting Interests

There are no conflict of interests.

Funding

N/A

\section{Author Contributions}

J.J. designed and performed experiments, analyzed data; and Y.K. designed experiments and wrote the paper; M.K. designed experiments and critical revision. Also, the authors discussed the results together and implications and commented on the manuscript at each stage.

\section{ORCID iDs}

Jeongho Jeong

Youngsun Kim

https://orcid.org/0000-0002-9935-6140 https://orcid.org/0000-0001-7338-4058

\section{REFERENCES}

Atcherson, S. R., Mendel, L. L., Baltimore, W. J., Patro, C., Lee, S., Pousson, M., et al. (2017). The effect of conventional and transparent surgical masks on speech understanding in individuals with and without hearing loss. Journal of the American Academy of Audiology, 28(1), 5867.

Cheon, S. H. \& Kim, Y. H. (2015, May 1). [Fine Dust Economics] A Boom in the Air Purifier and Yellow Sand Mask Industry against Fine Dust. Edaily. Retrieved from https://www.edaily.co.kr/news/read?newsid= 01203766609364656

Choi, E. J. (2020, March 15) "In a Place Like a Chicken Coop Where You Can't Use a Mask." Call Center Group Infection. Why? KBS News. Retrieved from http://news.kbs.co.kr/news/view.do?ncd=4402004.

Han, Y. K. \& Lee, K. W. (2020). A study on the Korea conversation speech level and spectrum in sound-treated environment. Audiology and Speech Research, 16(2), 133-139.

International Electrotechnical Commission (2011). Sound System Equipment-Part 16: Objective Rating of Speech Intelligibility by Speech Transmission Index (IEC 60286-16). (4th ed.). Geneva: International Electrotechnical Commission.

International Organization for Standardization (2003). Ergonomics-Assessment of Speech Communication (ISO 9921). Geneva: International Standard Organization.

International Organization for Standardization (2012). Acoustics-Measurement of Room Acoustic Parameters-Part 3: Open Plan Offices (ISO 3382-3). Geneva: International Standard Organization.

Kang, S. J. (2020, March 16). "6.59 Million Units to 12.91 Million Units" Mask Daily Production Doubled. Hitnews. Retrieved from http://www.hitnews.co.kr/news/articleView.html?idxno=15677.

Kim, M. R. (2018, April 30). A 'Smiling and Crying' Distributor Because of Fine Dust. Nexteconomy. Retrieved from https://www.nexteconomy. co.kr/news/articleView.html?idxno=11337.

Korea Research Institute of Standards and Science. (2009). Study on Gas Mask for its New Specification and Supply. Seoul: National Emergency Management Agency.

Kwon, J. D. (2020, March 13). "It Seems to Work 8 Hours in an Elevator" 98\% of Call Center Counselors Say "Work Environment Risk." The Hankyoreh. Retrieved from http://www.hani.co.kr/arti/society/society_ general/932472.html.

Mendel, L. L., Gardino, J. A., \& Atcherson, S. R. (2008). Speech understanding using surgical masks: A problem in health care? Journal of the 
American Academy of Audiology, 19(9), 686-695.

National Institute of Food and Drug Safety Evaluation. (2019, December 26). Guidelines for Reference Standards for Health Mask. National Institute of Food and Drug Safety Evaluation. Retrieved from https:// www.nifds.go.kr $/$ brd $/ \mathrm{m} \_15 /$ view.do?seq $=12791 \& \operatorname{srchFr}=\& \operatorname{srchTo}=\& s$ rchWord $=\& \operatorname{srchTp}=\&$ itm_seq_1 $=0 \&$ itm_seq_2 $=0 \&$ multi_itm $\mathrm{seq}=0 \&$ company_cd $=\&$ company_nm $=\&$ page $=6$.

Palmiero, A. J., Symons, D., Morgan, J. W., 3rd, \& Shaffer, R. E. (2016).
Speech intelligibility assessment of protective facemasks and air-purifying respirators. Journal of Occupational and Environmental Hygiene, 13(12), 960-968.

Radonovich, L. J., Jr, Yanke, R., Cheng, J., \& Bender, B. (2010). Diminished speech intelligibility associated with certain types of respirators worn by healthcare workers. Journal of Occupational and Environmental Hygiene, 7(1), 63-70. 